\title{
Andrographis peniculata: Capabilities against Free Radicals, Lipid Peroxidation, Hepatotoxicity, and Nephrotoxicity
}

\author{
Godwin O. Adejo ${ }^{1 *}$, Joseph M. Gnimintakpa', Olufunsho D. Olowoniyi², \\ Paulinus Obinna Matthew ${ }^{3}$ \\ ${ }^{1}$ Department of Biochemistry \& Molecular Biology, Federal University, Dutsin-Ma, Nigeria \\ ${ }^{2}$ Department of Biochemistry, Kaduna State University, Kaduna, Nigeria \\ ${ }^{3}$ Department of Biochemistry, Faculty of Science and Technology, Bingham University, Auta-Balefi, Nigeria \\ Email: *dradejogod@gmail.com
}

Received 4 March 2016; accepted 16 July 2016; published 19 July 2016

Copyright (C) 2016 by authors and OALib.

This work is licensed under the Creative Commons Attribution International License (CC BY).

http://creativecommons.org/licenses/by/4.0/

(c) $\underset{B Y}{0}$ Open Access

\section{Abstract}

This work was about Andrographis peniculata (Burm. F). Ab initio, the $\mathrm{LD}_{50}$ test showed non-toxicity at the highest administered dose of $5000 \mathrm{mg} / \mathrm{kg}$ in rats. Male albino Wistar rats were treated with daily single doses of ethanol extracts $(100 / 200 / 500 \mathrm{mg} / \mathrm{kg}$ ) of Andrographis peniculata (A.p.) for 14 days with intermittent administration, i.p., of $\mathrm{CCl}_{4}$ every four days. Liver and kidney TBARS concentrations showed lower values with increased doses of extract administration. In both cases,

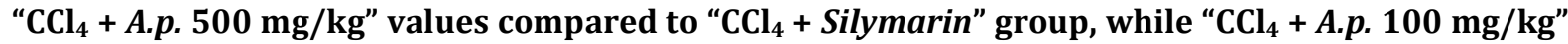
showed no significant difference from " $\mathrm{CCl}_{4}$ only" group. The "NC" (normal control) however, presented the least concentration of $66.17 \pm 2.74$ and $38.04 \pm 4.34 \mathrm{nmol} / \mathrm{mg}$ protein, respectively. Total and Indirect bilirubin concentrations indicated decreased values with increasing doses, such that respectively, the lowest values of $1.18 \pm 0.47$ and $0.98 \pm 0.31 \mathrm{mg} / \mathrm{dl}$ in the "CCl $4+A . p .500 \mathrm{mg} / \mathrm{kg}$ " group were observed. There was no significant difference among all the various groups except the "NC" which showed the least value. Urea and creatinine levels were significantly higher (p $\leq 0.05)$ in the " $\mathrm{CCl}_{4}$ only" group than all others. Liver function parameters, viz., AST and ALT indicated significantly higher values in the " $\mathrm{CCl}_{4}$ only" group, compared to all others $(\mathrm{p} \leq 0.05)$. Values obtained

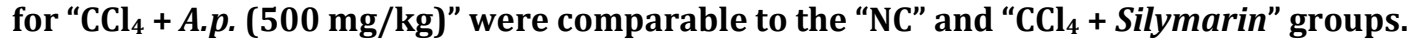

\section{Keywords}

Andrographis peniculata, Peroxidation, Hepatotoxicity, Nephrotoxicity

Subject Areas: Biochemistry

\footnotetext{
${ }^{*}$ Corresponding author.
}

How to cite this paper: Adejo, G.O., Gnimintakpa, J.M., Olowoniyi, O.D. and Matthew, P.O. (2016) Andrographis peniculata: Capabilities against Free Radicals, Lipid Peroxidation, Hepatotoxicity, and Nephrotoxicity. Open Access Library Journal, 3: e2541. http://dx.doi.org/10.4236/oalib.1102541 


\section{Introduction}

Free radicals are organic molecules responsible for aging, tissue damage, and possibly so many diseases. These molecules, are very unstable, therefore they look to bond with other molecules, destroying their health and further continuing the damage processes. Antioxidants present in many foods are molecules that prevent free radicals from harming healthy tissues.

Generally, free radicals attack the nearest stable molecule, "stealing” its electron. When the "attacked” molecule loses its electron, it becomes a free radical itself, beginning a chain reaction. Once the process is started, it can cascade, finally resulting in the disruption of a living cell. Some free radicals arise normally during metabolism. Sometimes the body's immune system purposefully creates them to neutralize viruses and bacteria. However, environmental factors such as pollution, radiation, cigarette smoke and herbicides can also spawn free radicals. Normally, the body can handle free radicals but if antioxidants are unavailable, or if the free radical production becomes excessive, damage can occur. Of particular importance is that free radical damage accumulates with age.

Antioxidants work to protect lipids from peroxidation by radicals. Antioxidants are effective because they are willing to give up their own electrons to free radicals. When a free radical gains the electron from an antioxidant, it no longer needs to attack the cell and the chain reaction of oxidation is broken [1]. After donating an electron, an antioxidant becomes a free radical by definition. Antioxidants in this state are not harmful because they have the ability to accommodate the change in electrons without becoming reactive. The body's physiological defense systems to counteract free radicals encompass endogenous antioxidant enzyme systems such as catalase, glutathione reductase and superoxide dismutase as well as carotene, vitamin C, vitamin E and selenium. All these molecules have an antioxidant effect due to their ability to transform reactive oxygen species (ROS) into stable and harmless compounds or by scavenging both ROS and reactive nitrogen species (RNS) with a redox based mechanism [2] and thus, confer protection against lipid peroxidative damage [3].

Andrographis paniculata (Burm. F.) Nees, commonly known as the king of bitters, it is an herbaceous plant belonging to the Acanthaceae family and is found throughout tropical and subtropical Asia, Southeast Asia, and India. It grows abundantly in south eastern Asia, including India, SriLanka, Pakistan, Java, Malaysia, and Indonesia, while it is cultivated extensively in India, China, and Thailand [4] [5]. Extract of this plant exhibits pharmacological activities such as immuno-stimulation [6] [7] anti-viral [8] and anti-bacterial [9].

Liver and kidney disorders are some of the world's major health problems [9]-[11]. Liver injury due to chemicals (or) infectious agents may lead to progressive liver fibrosis and ultimately cirrhosis and liver failure [12]. In a similar vein, kidney disorders are linked with oxidative stress arising from ROS which causes tissue damage by different mechanisms including the promotion of lipid peroxidation [13]. However, no effective treatment that delays disease progression and complications has yet been found. Several recent studies suggest that traditional herbs and micronutrients such as carotenoids and selenium may be useful for this purpose [14] [15]. Therefore, this research work was carried out to evaluate the free radical scavenging and other related cellular derangement normalizing abilities of A.p. against liver damage induced by $\mathrm{CCl}_{4}$.

\section{Materials and Methods}

Petroleum ether, ethanol, carbon tetrachloride $\left(\mathrm{CCl}_{4}\right)$, silymarin were obtained from Sigma Chemicals Limited, USA. Assay kits for bilirubin, total protein, total cholesterol, triglyceride, creatinine, urea, AST and ALT were obtained from RANDOX Laboratories Ltd., Ardmore, Diamond Road, Crumlin, Co. Antrim, United Kingdom.

\section{Equipments}

Spectrophotometer (6405 UV/VIS Jenway laboratory equipment, Japan); Soxhlet extractor (500 ml capacity, Tech-Lab scientific sdn. bath model EB-6.SKU); Centrifug (Labofuge 300 Heraeus, UK); Tissue homogenizer (Eberbach lab tools-Model 7000); rotary evaporator and oral cannula.

\section{Methodology}

\subsection{Collection and Identification of Plant Sample}

Plant leaves were obtained from cultivated fields of Bingham University, Nigeria. The plant was identified at National Institute for Pharmaceuticals and Research Development (NIPRD) Abuja by comparison with the 
voucher specimen number NIPRD/H/3720.

\subsection{Experimental Animals}

Apparently healthy male albino Wistar rats weighing between 160 - $220 \mathrm{~g}$ obtained from the animal house of College of Medicine, Bingham University Nasarawa state, Nigeria were used for the study. They were fed ad libithum with commercial rat feed pellets obtained from vital feed depot Gizzard Plaza, Mararaba, Nasarawa state Nigeria, and allowed clean drinking water. Rats were divided into six groups of five rats per group and treated as shown below:

\subsection{Animal Grouping}

Rats were treated over a period of 14 days and sacrificed under chloroform anesthesia by decapitation the next day after being fasted overnight. $\mathrm{CCl}_{4}$ only group was administered i.p. with $0.012 \mathrm{ml} / \mathrm{kg} \mathrm{CCl}_{4}$ every 4 days. Standard (Silymarin) and extract groups were orally administered with $0.0025 \mathrm{ml} / \mathrm{kg}$ Silymarin or A.P. (100, 200 and $500 \mathrm{mg} / \mathrm{kg}$ ) daily. However, every successive $4^{\text {th }}$ day from commencement of experiment, $0.012 \mathrm{ml} / \mathrm{kg}$ $\mathrm{CCl}_{4}$ was administered $1 \mathrm{hr}$ after Silymarin or A.p. administration. NC group received no treatment.

Blood samples for determination of sero-biochemical parameters were immediately collected. At necropsy, all rats were examined to identify lesions, and the specimen of the liver and kidney were quickly removed and fixed in $10 \%$ formol-saline for histopathology studies.

\subsection{Plant Extract Preparation}

This was carried out by collecting fresh plants and drying under shade then pulverized using mortar and pestle. This was followed by de-fatting with petroleum ether. Upon drying, powders were extracted with ethanol then concentrated with rotary evaporator at $60^{\circ} \mathrm{C}$. The pasty extracts were evaporated further over water bath at $45^{\circ} \mathrm{C}$ then transferred to desiccators containing activated silica gel until fully dry, then quantified [16] [17].

\subsection{Serum Samples Preparation}

This was done by allowing collected blood to stand for 1 hour to clot then centrifuged at $1000 \times \mathrm{g}$ for 15 min to separate the serum which was collected and stored in a freezer. The homogenates of liver and kidney portions were removed, blotted and weighed then processed for the relevant assays. These procedures have been previously described [18] [19].

\subsection{Determination of Parameters}

$\mathrm{LD}_{50}$ was determined using method described elsewhere [20]. Lipid peroxidation by thiobarbituric acid reacting substances (TBARS) was determined by procedure described elsewhere [21] with slight modifications as described recently [22]. Nephrological effects of administration of $\mathrm{CCl}_{4}$-induced tissue damages on total protein, creatinine and blood urea concentration were determined as per respective Randox assay kits manufacturer's guide. Hepatotoxicity in rats was induced by the method described previously [18] where $0.012 \mathrm{ml} / \mathrm{kg}$ doses of tetrachloromethane $\left(\mathrm{CCl}_{4}\right)$ in corn oil were injected by i.p. administration. Then, the activities of liver enzymes (AST and ALT) and concentrations of total, direct, indirect bilirubin were determined as per respective Randox assay kits manufacturer's guide. Lipid profile studies were also carried out by using Randox assay kits to determine the low density lipoprotein (LDL), high density lipoprotein (HDL), total glyceride (TG), and total cholesterol (TC) levels. Procedures were as per manufacturer's guide for the respective assay kits.

Finally, histological examination was further carried out after the animals were sacrificed by cervical decapitation. The liver tissues were excised, trimmed of fat and other connective tissues then, blotted dry and weighed on a balance. Sections of the liver from the autopsy samples were stored in $10 \%$ formalin and transferred to the Department of Pathology, Ahmadu Bello University teaching hospital Zaria for assessment. Slides were prepared, observed under the light microscope and photomicrographs were obtained.

\subsection{Statistics}

Data were presented as mean \pm SD of six determinations. The significance of difference was evaluated by 
ANOVA and Duncan Multiple Range test, with confidence limit set at 0.05 (95\%). SPSS version 16.0 and Microsoft excel (Windows 7) were used as analytical tools.

\subsection{Results}

As seen in Table 1, the percentage (\%) change in body weight comparison with mean body weight revealed decreased significant changes throughout the experiment. The " $\mathrm{CCl}_{4}$ only" group showed the greatest weight loss among the entire group while " $\mathrm{CCl}_{4}+$ A.p. $500 \mathrm{mg} / \mathrm{kg}$ " group presented the least. There was no observed body weight loss among the NC group. Liver/body and kidney/body weight ratios showed no significant percentage changes among all the groups. However, values obtained at doses of 200 and $500 \mathrm{mg} / \mathrm{kg}$ were not significantly different from the NC group.

There were significant increase $(\mathrm{p} \leq 0.05)$ in TBARS, creatinine and urea concentrations in the kidney and liver of the " $\mathrm{CCl}_{4}$ only" administered group compared to the $\mathrm{NC}$ and all the other groups except the " $\mathrm{CCl}_{4}+A \cdot p$. $100 \mathrm{mg} / \mathrm{kg}$ " group (Table 2). However, lower values were obtained with increased A.p. administration, such that, group treated with $500 \mathrm{mg} / \mathrm{kg}$ A.p. had values of TBARS, creatinine and urea comparable to $\mathrm{NC}$ or " $\mathrm{CCl}_{4}+\mathrm{Si}$ lymarin” groups (Table 2).

As depicted in Table 3, there was no significant change in the serum AST level of the silymarin and extract treatment groups as compared to the NC group except for the " $\mathrm{CCl}_{4}$ only" group which showed significantly higher AST level. Similar trend was also observed with the serum ALT levels. " $\mathrm{CCl}_{4}$ only" group showed a significantly higher ALT level than all the other groups $(\mathrm{p}<0.05)$. However, decreased AST and ALT levels were in the order of increasing doses of A.p. administered. Similar patterns observed with liver enzymes were also found in bilirubin concentrations. However, no significant differences were found between the " $\mathrm{CCl}_{4}$ only" group and the A.p. administered groups except those that received the highest dose of A.p. $500 \mathrm{mg} / \mathrm{kg}$.

In Table 4, the concentrations of LDL, TG and TC were significantly higher $(\mathrm{p}<0.05)$ in the " $\mathrm{CCl}_{4}$ only" group

Table 1. Percentage (\%) change in body, liver and kidney weight changes in rats treated with ethanolic leaf extracts of A.p.

\begin{tabular}{cccc}
\hline $\begin{array}{c}\text { Treatment } \\
\text { Group }\end{array}$ & \% change in body weight & $\begin{array}{c}\text { \% change in liver/ body } \\
\text { weight ratio }\end{array}$ & $\begin{array}{c}\text { \% change in kidney/body } \\
\text { weight ratio }\end{array}$ \\
\hline Normal Control (NC) & $4.30 \pm 1.45^{\mathrm{b}}$ & $3.43 \pm 0.15^{\mathrm{b}}$ & $0.34 \pm 0.07^{\mathrm{b}}$ \\
$\mathrm{CCl}_{4}$ only & $-6.05 \pm 1.60^{\mathrm{a}}$ & $2.59 \pm 0.39^{\mathrm{ac}}$ & $0.27 \pm 0.07^{\mathrm{c}}$ \\
$\mathrm{CCl}_{4}+$ silymarin & $-3.29 \pm 1.48^{\mathrm{c}}$ & $2.92 \pm 0.94^{\mathrm{c}}$ & $0.26 \pm 0.12^{\mathrm{c}}$ \\
$\mathrm{CCl}_{4}+$ A.p. $100 \mathrm{mg} / \mathrm{kg}$ & $-2.18 \pm 0.09^{\mathrm{cd}}$ & $2.63 \pm 0.74^{\mathrm{c}}$ & $0.23 \pm 0.08^{\mathrm{a}}$ \\
$\mathrm{CCl}_{4}+$ A.p. $200 \mathrm{mg} / \mathrm{kg}$ & $-2.68 \pm 0.25^{\mathrm{c}}$ & $3.37 \pm 0.32^{\mathrm{b}}$ & $0.32 \pm 0.02^{\mathrm{b}}$ \\
$\mathrm{CCl}_{4}+$ A.p. $500 \mathrm{mg} / \mathrm{kg}$ & $-1.68 \pm 0.39^{\mathrm{d}}$ & $3.51 \pm 0.11^{\mathrm{b}}$ & $0.36 \pm 0.04^{\mathrm{b}}$ \\
\hline
\end{tabular}

Values are expressed as mean $\pm S D$, $(n=5)$. No significant difference between values bearing same alphabets $(p \leq 0.05)$.

Table 2. TBARS, urea and creatinine concentration in rats treated with ethanolic leaf extract of A.p.

\begin{tabular}{|c|c|c|c|c|c|}
\hline \multirow{2}{*}{$\begin{array}{l}\text { Treatment } \\
\text { Group }\end{array}$} & \multicolumn{2}{|c|}{$\begin{array}{c}\text { TBARS } \\
\text { (nmol/mg protein) }\end{array}$} & \multirow{2}{*}{$\begin{array}{c}\text { Total } \\
\text { protein } \\
\text { (nmol/mg) }\end{array}$} & \multirow{2}{*}{$\begin{array}{c}\text { Creatinine } \\
\text { (nmol/mg protein) }\end{array}$} & \multirow{2}{*}{$\begin{array}{l}\text { Urea } \\
\text { (mg/dl) }\end{array}$} \\
\hline & Liver & Kidney & & & \\
\hline Normal Control & $66.17 \pm 2.74^{\mathrm{a}}$ & $38.04 \pm 4.34^{\mathrm{ac}}$ & $36.40 \pm 2.61^{\mathrm{d}}$ & $1.8 \pm 0.62^{c}$ & $41.46 \pm 6.92^{\mathrm{d}}$ \\
\hline $\mathrm{CCl}_{4}$ only & $94.79 \pm 1.16^{\mathrm{b}}$ & $46.96 \pm 4.47^{\mathrm{b}}$ & $27.36 \pm 3.17^{\mathrm{ac}}$ & $3.64 \pm 0.36^{b}$ & $50.61 \pm 7.47^{b}$ \\
\hline $\mathrm{CCl}_{4}+$ silymarin & $74.62 \pm 2.69^{c}$ & $41.98 \pm 4.60^{\mathrm{c}}$ & $29.98 \pm 1.85^{\mathrm{c}}$ & $2.88 \pm 0.72^{\mathrm{d}}$ & $34.55 \pm 6.91^{\mathrm{e}}$ \\
\hline $\mathrm{CCl}_{4}+$ A.p. $100 \mathrm{mg} / \mathrm{kg}$ & $93.40 \pm 1.31^{\mathrm{b}}$ & $45.55 \pm 3.91^{b}$ & $44.07 \pm 1.60^{\mathrm{b}}$ & $3.01 \pm 0.91^{\text {bd }}$ & $41.47 \pm 9.76^{\mathrm{d}}$ \\
\hline $\mathrm{CCl}_{4}+$ A.p. $200 \mathrm{mg} / \mathrm{kg}$ & $86.59 \pm 2.03^{d}$ & $41.29 \pm 4.51^{\mathrm{c}}$ & $39.68 \pm 2.66^{\mathrm{d}}$ & $1.68 \pm 0.55^{c}$ & $20.70 \pm 6.60^{\mathrm{ac}}$ \\
\hline $\mathrm{CCl}_{4}+$ A.p. $500 \mathrm{mg} / \mathrm{kg}$ & $75.99 \pm 1.46^{\mathrm{c}}$ & $39.42 \pm 3.00^{c}$ & $31.91 \pm 1.41^{\mathrm{c}}$ & $1.32 \pm 0.42^{\mathrm{a}}$ & $18.24 \pm 3.98^{\mathrm{a}}$ \\
\hline
\end{tabular}

Values are expressed as mean $\pm S D$, $(n=5)$. No significant difference between values bearing same superscripts $(p \leq 0.05)$. 
Table 3. Liver enzymes levels and Bilirubin (Total, direct and indirect) concentrations and in albino Wistar rats treated with ethanolic leaf extract of A.p. for 14 days after administration of $\mathrm{CCl}_{4}$.

\begin{tabular}{cccccc}
\hline \multirow{2}{*}{$\begin{array}{c}\text { Treatment } \\
\text { Group }\end{array}$} & \multicolumn{2}{c}{ Concentration of liver enzymes $(\mathrm{u} / \mathrm{l})$} & \multicolumn{3}{c}{ Bilirubin concentration $(\mathrm{mg} / \mathrm{dl})$} \\
\cline { 2 - 6 } & AST & ALT & Direct & Indirect & Total \\
\hline Normal Control & $16.49 \pm 1.98^{\mathrm{c}}$ & $136.96 \pm 9.92^{\mathrm{c}}$ & $0.12 \pm 0.07^{\mathrm{a}}$ & $2.47 \pm 0.39^{\mathrm{d}}$ & $2.58 \pm 0.34^{\mathrm{c}}$ \\
$\mathrm{CCl}_{4}$ only & $26.06 \pm 1.14^{\mathrm{b}}$ & $158.53 \pm 4.70^{\mathrm{b}}$ & $0.24 \pm 0.02^{\mathrm{b}}$ & $3.11 \pm 0.56^{\mathrm{c}}$ & $3.34 \pm 0.54^{\mathrm{b}}$ \\
$\mathrm{CCl}_{4}+$ silymarin & $17.71 \pm 3.65^{\mathrm{c}}$ & $142.53 \pm 4.87^{\mathrm{c}}$ & $0.20 \pm 0.02^{\mathrm{d}}$ & $2.24 \pm 0.54^{\mathrm{d}}$ & $2.44 \pm 0.56^{\mathrm{c}}$ \\
$\mathrm{CCl}_{4}+$ A.p. $100 \mathrm{mg} / \mathrm{kg}$ & $18.00 \pm 2.71^{\mathrm{c}}$ & $151.28 \pm 8.84^{\mathrm{c}}$ & $0.23 \pm 0.01^{\mathrm{c}}$ & $3.35 \pm 0.25^{\mathrm{bc}}$ & $3.59 \pm 0.24^{\mathrm{b}}$ \\
$\mathrm{CCl}_{4}+$ A.p. $200 \mathrm{mg} / \mathrm{kg}$ & $17.36 \pm 1.97^{\mathrm{c}}$ & $147.46 \pm 6.48^{\mathrm{c}}$ & $0.24 \pm 0.01^{\mathrm{bc}}$ & $2.81 \pm 0.97^{\mathrm{cd}}$ & $3.04 \pm 0.96^{\mathrm{bc}}$ \\
$\mathrm{CCl}_{4}+$ A.p. $500 \mathrm{mg} / \mathrm{kg}$ & $16.41 \pm 1.85^{\mathrm{ac}}$ & $128.49 \pm 3.05^{\mathrm{ac}}$ & $0.20 \pm 0.02^{\mathrm{d}}$ & $0.98 \pm 0.31^{\mathrm{a}}$ & $1.18 \pm 0.47^{\mathrm{a}}$ \\
\hline
\end{tabular}

Values are expressed as mean $\pm S D$, $(n=5)$. No significant difference between values bearing same alphabets $(p \leq 0.05)$.

Table 4. Lipid profiles of albino Wistar rats treated with ethanolic leaf extract of A.p. for 14 days after administration of $\mathrm{CCl}_{4}$.

\begin{tabular}{ccccc}
\hline $\begin{array}{c}\text { Treatment } \\
\text { Group }\end{array}$ & \multicolumn{3}{c}{ Lipid profile } \\
\cline { 2 - 5 } Normal Control & HDL $(\mathrm{mg} / \mathrm{dl})$ & LDL $(\mathrm{mg} / \mathrm{dl})$ & $\mathrm{TG}(\mathrm{mg} / \mathrm{dl})$ & TC $(\mathrm{U} / \mathrm{I})$ \\
$\mathrm{CCl}{ }_{4}$ only & $38.82 \pm 0.79^{\mathrm{c}}$ & $36.67 \pm 1.51^{\mathrm{c}}$ & $75.22 \pm 0.16^{\mathrm{a}}$ & $41.72 \pm 0.31^{\mathrm{d}}$ \\
$\mathrm{CCl}_{4}+$ silymarin & $27.11 \pm 1.12^{\mathrm{b}}$ & $66.97 \pm 0.47^{\mathrm{a}}$ & $157.42 \pm 0.08^{\mathrm{d}}$ & $97.11 \pm 0.51^{\mathrm{a}}$ \\
$\mathrm{CCl}_{4}+$ A.p. $100 \mathrm{mg} / \mathrm{kg}$ & $37.51 \pm 1.05^{\mathrm{c}}$ & $38.78 \pm 0.28^{\mathrm{c}}$ & $82.08 \pm 0.10^{\mathrm{b}}$ & $32.24 \pm 0.14^{\mathrm{d}}$ \\
$\mathrm{CCl}_{4}+$ A.p. $200 \mathrm{mg} / \mathrm{kg}$ & $33.08 \pm 2.51^{\mathrm{c}}$ & $44.21 \pm 0.84^{\mathrm{b}}$ & $112.22 \pm 0.20^{\mathrm{c}}$ & $53.35 \pm 0.21^{\mathrm{c}}$ \\
$\mathrm{CCl}_{4}+$ A.p. $500 \mathrm{mg} / \mathrm{kg}$ & $40.43 \pm 1.45^{\mathrm{c}}$ & $35.01 \pm 1.05^{\mathrm{c}}$ & $78.02 \pm 0.12^{\mathrm{a}}$ & $36.97 \pm 0.64^{\mathrm{d}}$ \\
\hline
\end{tabular}

Values are expressed as mean $\pm \mathrm{SD}$, $(\mathrm{n}=5)$. No significant difference between values bearing same alphabets in the same column $(\mathrm{p} \leq 0.05)$.

than the "NC" and all other groups except in HDL concentration where the least concentration was recorded.

Statistically significant increases in LDL, TG and TC among the " $\mathrm{CCl}_{4}$ only" rats group indicated hyperlipidemic and hypercholesterolemic effects of the hepatotoxin, while the decreased concentration values with increased doses of the extract showed the antihyperlipidemic and antihypercholesterolemic effects of A.p. extract in a dose-dependent manner. On the contrary, an observed increase in HDL among all the rat groups treated with A.p. after $\mathrm{CCl}_{4}$ administrations was equally indicative of the antihyperlipidemic effect of the plant extracts. HDL concentration in the " $\mathrm{CCl}_{4}$ only" group was significantly low due to the effect of $\mathrm{CCl}_{4}$.

Hisptopathological slides have shown the protective capabilities of A.p. (Plate $1(\mathrm{~F})$ ) especially at $500 \mathrm{mg} / \mathrm{kg}$ comparable to silymarin (Plate 1(C)) even though at a lower dose of $200 \mathrm{mg} / \mathrm{kg}$ (Plate 1(E)) where there were evidences of liver tissue regeneration. Furthermore, (Plate 2(B)) indicated a similar pattern with respect to the protective effect of A.p. against kidney tissue damage as a result of $\mathrm{CCl}_{4}$ administrations. Regeneration of cells of the damaged tissue seemed to be in a dose-dependent manner (Plates 2(D)-(F)).

\section{Discussion and Conclusions}

Herbal medicines derived from plant extracts are gaining greater attention due to their effectiveness as chemo-therapeutic agents. As such there has been increased utilization of these herbs in treating a wide variety of diseases and the use of herbal medicines have continued to expand rapidly across the world. In fact, vast numbers of people now solely rely on herbal medicines or herbal products for their primary health care requirements [23].

The present study was undertaken to demonstrate the free radical scavenging abilities of ethanolic leaf extracts of Andrographis peniculata against induced liver damage by $\mathrm{CCl}_{4}$ and the toxic effects of similar doses in rats. $\mathrm{CCl}_{4}$ is one of the most widely used toxicants for experimental induction of liver damage in laboratory animals [24]. $\mathrm{CCl}_{4}$ is biotransformed by cytochrome P450 system in the endoplasmic reticulum to produce 


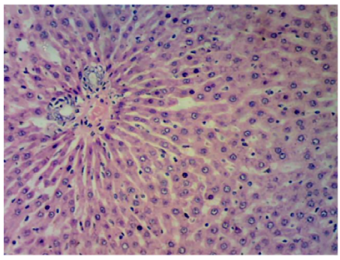

A. Normal liver tissue.

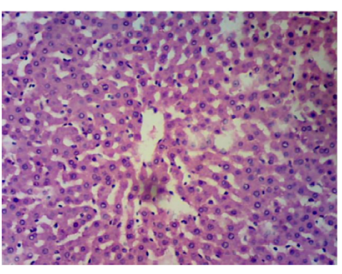

D. Liver tissue with necrotic changes of hepatocytes with mild vacuolation $\left(\mathrm{CCl}_{4}+\right.$ A.p. 100mg/kg).

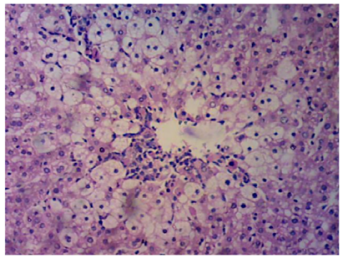

B. Liver section showing fatty change and hydropic change with necrosis and vacuolation $\left(\mathrm{CCl}_{4}\right.$ only).

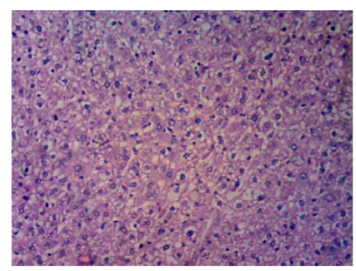

E. Mild regeneration of the hepatocytes and sinusoids with hydropic change $\left(\mathrm{CCl}_{4}+\right.$ A.p. 200mg/kg).

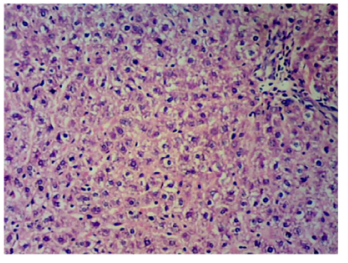

C. Normal liver tissue showing hepatocytes and sinusoids well preserved $\left(\mathrm{CCl}_{4}+\right.$ Silymarin)

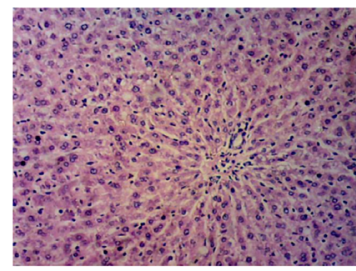

F. Normal liver tissue showing well regenerated hepatocytes and sinusoids $\left(\mathrm{CCl}_{4}+\right.$ A.p. 500mg/kg).

Plate 1. Photomicrographs of liver sections of $\mathrm{CCl}_{4}$-induced hepatotoxicity in rats pre-administered with varying doses An-

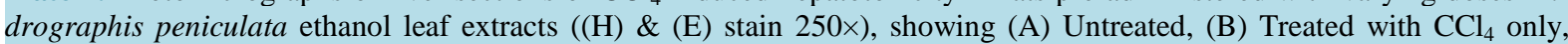
(C)-(F) Treated with: Silymarin, 100, 200 and $500 \mathrm{mg} / \mathrm{kg}$ of extract after $\mathrm{CCl}_{4}$ administration, respectively.

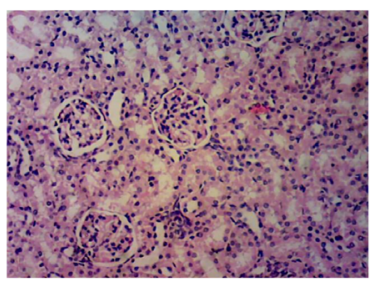

A. Normal kidney tissue.

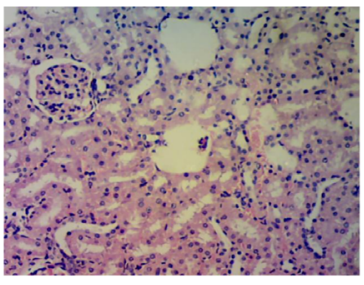

D. Mildly regenerated glomerular and tubular tissues observed $\left(\mathbf{C C l}_{4}+\right.$ A.p. $100 \mathrm{mg} / \mathrm{kg}$ ).

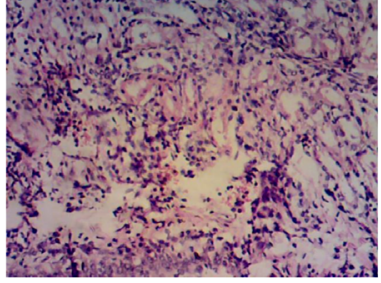

B. Highly necrotic kidney section ( $\mathbf{C C l}_{\mathbf{4}}$ only).

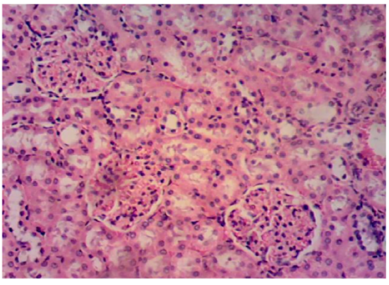

E. Kidney section showed regeneration of glomerulus and tubules with increased mitotic activities $\left(\mathbf{C C l}_{4}+\right.$ A.p. $200 \mathrm{mg} / \mathrm{kg}$ ).

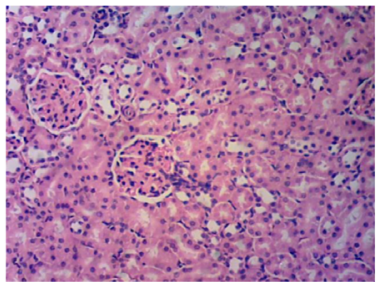

C. Regeneration of kidney tubules showing normal kidney section $\left(\mathbf{C C l}_{4}+\right.$ Silymarin).

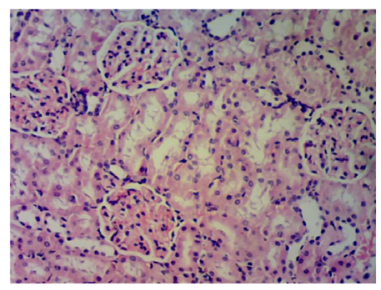

F. Kidney tissues are preserved with well regenerated glomerulus and tubules $\left(\mathbf{C C l}_{4}+\boldsymbol{A}\right.$.p. $500 \mathrm{mg} / \mathrm{kg}$ ).

Plate 2. Photomicrographs of kidney sections of $\mathrm{CCl}_{4}$-induced hepatotoxicity in rats pre-administered with varying doses Andrographis peniculata ethanol leaf extracts $(\mathrm{H}) \&(\mathrm{E})$ stain $\times 250)$, showing $(\mathrm{A})$ Untreated, (B) Treated with $\mathrm{CCl}_{4}$ only, (C)-(F) Treated with: Silymarin, 100, 200 and $500 \mathrm{mg} / \mathrm{kg}$ of extract after $\mathrm{CCl}_{4}$ administration, respectively. 
trichloromethyl free radical (" $\mathrm{CCl}_{3}$ ). Trichloromethyl free radical when combined with cellular lipids and proteins in the presence of oxygen form trichloromethylperoxyl radical, which attacks lipids on the membrane of endoplasmic reticulum faster than a trichloromethyl free radical. Thus, trichloromethylperoxyl free radical elicits lipid peroxidation, eventual cell necrosis and finally resulting to cell death [25]. The free radical scavenging abilities of Andrographis peniculata is inherent in its constituents, the Andrographolides [26] [27] which inhibit the aromatase activity of cytochrome P450 thereby favouring liver regeneration [28] [29].

Intra-peritoneal administration of $\mathrm{CCl}_{4}$ caused significant liver damage as evidenced by altered biochemical parameters in the findings here. There was a significant reduction in body weight of the " $\mathrm{CCl}_{4}$ only" group as compared to the various extract treated groups, silymarin treated group and the normal control group. $\mathrm{CCl}_{4}$ significantly ( $\mathrm{p}<0.05$ ) increased serum levels of ALT, AST, urea, creatinine, total, direct and indirect bilirubin levels, and also lipidemic parameters, namely, low density lipoprotein, triglycerides and total cholesterol. Treatment with the ethanolic leaf extract of Andrographis peniculata attenuated the elevated enzyme levels towards normal ranges. The hepatoprotective and nephroprotective efficacies of the extract were comparable to that of the standard drug-silymarin, used in the experiment. These effects against $\mathrm{CCl}_{4}$ intoxication was further confirmed by histopathological examinations. The liver samples of " $\mathrm{CCl}_{4}$ only" administered rats showed cell vacuolation, necrosis and degeneration of nuclei and bile capillaries. However, in the extract-treated groups, mild degenerative changes and marked recovery from necrosis and degeneration of bile capillaries in the liver samples were evident. Also, kidney samples showed necrosis in the " $\mathrm{CCl}_{4}$ only" administered rats whereas, these tissues were preserved with well regenerated glomerulus and tubules as a result of the A.p. extracts treatments.

The results of this study have clearly demonstrated the antiperoxidative, hepatoprotective and nephroprotective properties of Andrographis peniculata which were likely as a result of the free radical scavenging properties of the extract, equally shown to be safe even at very high dose.

\section{References}

[1] Dekkers, J.C., van Doornen, L.J.P. and Kemper, H.C.G. (1996) The Role of Antioxidant Vitamins and Enzymes in the Prevention of Exercise-Induced Muscle Damage. Sports Medicine, 21, 213-238. http://dx.doi.org/10.2165/00007256-199621030-00005

[2] Valko, M., Rhodes, C.J., Moncol, J., Izakovic, M. and Mazur, M. (2006) Free Radical Metals and Antioxidants in Oxidative Stress-Induced Cancer. Chemico-Biological Interactions, 160, 1-40. http://dx.doi.org/10.1016/j.cbi.2005.12.009

[3] Andreyev, A.Yu., Kushnareva, Yu.E. and Starkov, A.A. (2005) Mitochondrial Metabolism of Reactive Oxygen Species. Biochemistry (Moscow), 70, 200-214. http://dx.doi.org/10.1007/s10541-005-0102-7

[4] Zhang, X. (2004) WHO Monograph on Selected Medicinal Plants. Vol. 2, World Health Organization, Geneva.

[5] Chen, W. and Liang, X. (1982) Deoxyandrographolide19 $\beta$-D-Glucoside from the Leaves of A. paniculata. Planta Medica, 15, 245-246.

[6] Rajagopal, S., Kumar, R.A., Deevi, D.S., Satyanarayana, C. and Rajagopal, R. (2003) Andrographolide, a Potential Cancer Therapeutic Agent Isolated from Andrographis paniculata. Journal of Experimental Therapeutics \& Oncology, 3, 147-158. http://dx.doi.org/10.1046/j.1359-4117.2003.01090.x

[7] Kumar, R.A., Sridevi, K., Kumar, N.V., Nanduri, S. and Rajagopal, S. (2004) Anticancer and Immunostimulatory Compounds from Andrographis paniculata. Journal of Ethnopharmacology, 92, 291-295. http://dx.doi.org/10.1016/j.jep.2004.03.004

[8] Calabrese, C., Berman, S.H., Babish, J.G., Ma, X.F., Shinto, L., Dorr, M., Wells, K., Wenner, C.A., et al. (2000) A Phase I Trial of Andrographolide in HIV Positive Patients and Normal Volunteers. Phytotherapy Research, 14, 333338. http://dx.doi.org/10.1002/1099-1573(200008)14:5<333::AID-PTR584>3.0.CO;2-D

[9] Pratibha, S., Srivastava, M.M. and Khemani, L.D. (2009) Renoprotective Effects of Andrographis paniculata (Burm. f.) Nees in Rats. Upsala Journal of Medical Sciences, 114, 136-139. http://dx.doi.org/10.1080/03009730903174321

[10] Bruck, R.R., Hershkoviz, O., Lider, H., Aeed, L., Zaidel, Z., Matas, J.B. and Halpern, Z. (1996) Inhibition of Experimentally-Induced Liver Cirrhosis in Rats by a Nonpeptidic Mimetic of the Extracellular Matrix-Associated Arg-GlyAsp Epitope. Journal of Hepatology, 24, 731-738. http://dx.doi.org/10.1016/S0168-8278(96)80270-4

[11] Noori, S., Nayab, R., Madiha, Q. and Tabassum, M. (2009) Reduction of Carbon Tetrachloride-Induced Rat Liver Injury by Coffee and Green Tea. Pakistan Journal of Nutrition, 8, 452-458. http://dx.doi.org/10.3923/pjn.2009.452.458

[12] Anand, B.S. (1999) Cirrhosis of Liver. Western Journal of Medicine, 171, 110-115.

[13] Ozbek, E. (2012) Induction of Oxidative Stress in Kidney. Hindawi Publishing Corporation. International Journal of 
Nephrology, 2012, Article ID: 465897. http://dx.doi.org/10.1155/2012/465897

[14] Hinds, T.S., Wesk, W.L. and Knight, E.M. (1997) Carotenoids and Retinoids: A Review of Research, Clinical and Public Health Applicationsz. The Journal of Clinical Pharmacology, 37, 551-558. http://dx.doi.org/10.1002/j.1552-4604.1997.tb04336.X

[15] We, Y.T., Liu, D.W., Ding, L.Y., Li, Q. and Xiao, Y.H. (2004) Therapeutic Effects and Molecular Mechanical of Antifibrosis Herbs and Selection on Rats with Hepatic Fibrosis. World Journal of Gastroenterology, 10, 703-706. http://dx.doi.org/10.3748/wjg.v10.i5.703

[16] Adejo, G.O., Atawodi, S.E., Ameh, D.A. and Ibrahim, S. (2014) Anti-Peroxidative, Protective and Ameliorative Properties of Methanol Extract of All Parts of Morinda Lucida Benth in $\mathrm{CCl}_{4}$-Induced Liver Injury. Natural Products Chemistry \& Research, S1, 003.

[17] Mishra, B.B., Gautam, S. and Sharma, A. (2006) Microbial Decontamination of Tea (Camellia sinensis) by Gamma Radiation. Journal of Food Science, 71, M151-M156. http://dx.doi.org/10.1111/j.1750-3841.2006.00057.x

[18] Gyamfi, M.A., Yonamine, M. and Aniya, Y. (1999) Free-Radical Scavenging Action of Medicinal Herbs from Ghana: Thonningia sanguinea on Experimentally-Induced Liver Injuries. General Pharmacology, 32, 661-667. http://dx.doi.org/10.1016/S0306-3623(98)00238-9

[19] Usoh, I.F., Akpan, E.J., Etim, E.O. and Farombi, E.O. (2005) Antioxidant Actions of Dried Flower Extracts of Hibiscus sabdariffa L. On Sodium Arsenite-Induced Oxidative Stress in Rats. Pakistan Journal of Nutrition, 4, 135-141. http://dx.doi.org/10.3923/pjn.2005.135.141

[20] Lorke, D. (1983) A New Approach to Practical Acute Toxicity Testing. Archives of Toxicology, 54, 275-287. http://dx.doi.org/10.1007/BF01234480

[21] Ohkawa, H., Ohishi, N. and Yagi, K. (1979) Assay for Lipid Peroxides in Animal Tissue by Thiobarbituric Acid Reaction. Analytical Biochemistry, 2, 351-358. http://dx.doi.org/10.1016/0003-2697(79)90738-3

[22] Adejo, G.O., Agbali, F.A. and Otokpa, O.S. (2015) Antioxidant, Total Lycopene, Ascorbic Acid and Microbial Load Estimation in Powdered Tomato Varieties Sold in Dutsin-Ma Market. Open Access Library Journal, 2, e1768. http://dx.doi.org/10.4236/oalib.1101768

[23] Singh, A.P. (2005) The Lost Glory of Folk Medicine. Ethnobotanical Leaflets, 2005, 29.

[24] Tsukamoto, H., Matsuoka, M. and French, S.W. (1990) Experimental Models of Hepatic Fibrosis: A Review. Seminars in Liver Disease, 10, 56-65. http://dx.doi.org/10.1055/s-2008-1040457

[25] Recknagel, R.O., Glende, E.A., Dolak, J.A. and Waller, R.L. (1989) Mechanisms of Carbon Tetrachloride Toxicity. Pharmacology \& Therapeutics, 43, 139-154. http://dx.doi.org/10.1016/0163-7258(89)90050-8

[26] Deshwal, N., Sharma, A.K. and Sharma, P. (2011) Review on Hepatoprotective Plants. International Journal of Pharmaceutical Sciences Review and Research, 7, 15-26.

[27] Bhragual, D.D., Kumar, N., Garg, V.K. and Sharma, P.K. (2010) Review on Plants Having Hepatoprotective Activity. Journal of Pharmacy Research, 3, 2077-2082.

[28] Brent, J.A. and Rumack, B.H. (1993) Role of Free Radicals in Toxic Hepatic Injury. Clinical Toxicology, 31, $173-196$.

[29] Seakins, A. and Robinson, D.S. (1963) The Effect of the Admin-Istration of Carbon Tetrachloride on the Formation of Plasma Lipoproteins in the Rats. Biochemical Journal, 86, 401-407. http://dx.doi.org/10.1042/bj0860401

- Publication on a daily basis

Open Access Library

- 9 subject areas of science, technology and medicine

- Fair and rigorous peer-review system

- Fast publication process

- Article promotion in various social networking sites (LinkedIn, Facebook, Twitter, etc.)

- Widely-targeted and multidisciplinary audience to read your research

Submit Your Paper Online: Click Here to Submit

Contact Us: service@oalib.com 